\title{
Suvremeni procesi stvaranja javnih politika: kako istraživati transfer?
}

\author{
MARJETA ŠINKO \\ Fakultet političkih znanosti, Sveučilište u Zagrebu
}

\begin{abstract}
Sažetak
Istraživači javnih politika od druge polovice 20 . stoljeća sve više analitičke pažnje posvećuju prijenosu javnih politika iz jednog političkog djelokruga u drugi. Pritom se koriste konceptima poput difuzije, konvergencije i transfera javnih politika. Transfer javnih politika, najmlađi od navedenih pristupa, dobiva na zamahu nakon druge polovice devedesetih godina prošlog stoljeća te je u posljednjih dvadeset godina izrastao u respektabilan, naveliko citiran i korišten istraživački pristup. Ovaj se rad može shvatiti kao historijat istraživanja prijenosa javnih politika između političkih djelokruga. Pored pregleda evolucije pristupa ponudit će se i izvorna sistematizacija i demarkacija različitih studija. Rad se zaključuje uvidom kako su studije transfera distinktivne u odnosu na studije konvergencije i difuzije. Odlikuje ih procesni analitički fokus, usmjerenost na razumijevanje djelovanja aktera, kvalitativna metodologija te korištenje malih uzoraka. U radu se zastupa mišljenje kako su studije transfera javnih politika izvrstan heuristički alat jer omogućuju multidimenzionalno istraživanje procesa stvaranja javnih politika.
\end{abstract}

Ključne riječi: javne politike, transfer, difuzija, konvergencija, promjena javnih politika

Znanstvenici - osobito oni iz različitih disciplina - trebaju [...] pokušati upotrijebiti iste pojmovne sklopove kako bi se osiguralo da su istinski $u$ dijalogu i da ne bacaju riječi u vjetar (Benson i Jordan, 2012: 335).

\section{Uvod}

Suvremeni svijet pruža izazove istraživačima javnih politika. Tehnološke inovacije omogućile su veći i brži uvid u javnopolitička rješenja primijenjena u drugim političkim sustavima te nastanak i brzo reagiranje transnacionalnih, globalnih zagova- 
račkih mreža. Istovremeno, preklapajući međunarodni režimi dobivaju na važnosti u procesima stvaranja javnih politika: njihovi zahtjevi postaju izvor ili razlog promjenama i prilagodbama javnih politika. Čak i ovakva opservacija o stanju suvremenog svijeta daje uvide u elementarne izazove s kojima se suočavaju politolozi koji se bave istraživanjima unutar grane javnih politika. Akteri uključeni u proces stvaranja javnih politika mogu biti domaći ili međunarodni, situirani na supranacionalnoj, nacionalnoj ili subnacionalnoj razini, a formulirane i implementirane javne politike autohtono inovirane ili alohtone i importirane. Suvremen proces stvaranja javnih politika je mnogostruko usložnjen, on je multidimenzionalan i multirazinski, i sve manje nacionalan, autonoman i suveren.

Istraživači javnih politika od druge polovice 20. stoljeća sve više analitičke pažnje posvećuju prijenosu javnih politika iz jednog političkog djelokruga u drugi. Pritom se koriste konceptima i razvijaju koncepte poput difuzije, konvergencije, izomorfizma i transfera javnih politika, koji se pak često smještaju u širu literaturu o europeizaciji ili globalizaciji javnih politika. Transfer javnih politika, najmlađi od navedenih pristupa, dobiva na zamahu nakon druge polovice devedesetih godina prošlog stoljeća te je u posljednjih dvadeset godina izrastao u respektabilan, naveliko citiran i korišten istraživački pristup. ${ }^{1}$ Uzevši u obzir značaj tog pristupa unutar međunarodne politologijske zajednice (akademska razina) te značaj različitih međunarodnih režima za nastanak javnih politika u Hrvatskoj (praktična razina), mogli bismo očekivati velik interes hrvatskih istraživača za transfer javnih politika.

Kratko pretraživanje ${ }^{2}$ Portala znanstvenih časopisa Republike Hrvatske Hrčak pokazuje kako tome nije tako (Hrcak.srce.hr, 2017). Pretraga članaka koristeći sintagmu "transfer" i "javne politike" kroz cjelovit tekst dala je 103 rezultata. Kada su se ti rezultati dodatno filtrirali koristeći kriterij prezimena ključnog autora unutar studija transfera javnih politika, broj rezultata drastično je pao na tri. Kada se, pak, pretraga vršila po kriteriju "transfera javnih politika" kao ključnih riječi, broj rezultata pao je na samo dva članka u kojima autori koriste transfer javnih politika kao okvir svojih istraživanja (Mataković, 2011 o politici financiranja političkih stranaka; Petković, 2017 o kaznenoj politici). Pored navedenih znanstvenih radova dostupnih na Hrčku nužno je spomenuti i nekoliko drugih u okviru hrvatske izdavačke produkcije: članak Tihomira Žiljaka o transferu obrazovnih politika (Žiljak,

1 Prema Google znalcu dva ključna teksta (Dolowitz i Marsh, 1996; 2000), kojima se utemeljuju i utvrđuju studije transfera, referencirana su više od 4.500 puta; u sklopu studija objavljene su brojne knjige i članci (vidi Dolowitz i Marsh, 1996; Benson i Jordan, 2011; Dussauge-Laguna, 2012), a priređeno je i više posebnih brojeva časopisa poput Policy Studies i Political Studies Review.

2 Pretraživali su se samo politološki znanstveni radovi na hrvatskom jeziku. 
2006), ${ }^{3}$ natuknicu o transferu javnih politika u Pojmovniku javnih politika (Petek, 2014b: 164-166) te prijevod knjige Proces stvaranja javnih politika u kojoj se transferu javnih politika kratko posvećuje pažnja u okviru poglavlja o formulaciji (Hill, 2010: 173-175).

Što se iz ovog kratkog prikaza može pretpostaviti o hrvatskoj izdavačkoj produkciji po pitanju transfera javnih politika? Prvo, velika većina autora u politologijskoj zajednici koristi transfer u doslovnom smislu - kao tuđicu kojom se opisuje prijenos javnih politika. Oni se ne situiraju unutar studija transfera javnih politika niti koriste transfer javnih politika kao koncept ili istraživački okvir. Drugo, hrvatska znanstvena produkcija ne reflektira značaj te teme niti je u suglasju s interesom za tu temu koji je iskazan na međunarodnoj razini. Uzevši u obzir proliferaciju i važnost raznorodnih međunarodnih režima od druge polovice 20. stoljeća naovamo, predmnijeva se kako razlog tomu nije manjak istraživačkog interesa, već nedovoljna informiranost o tom istraživačkom pristupu i njegovoj primjenjivosti na ovakve istraživačke situacije. Treće, kada se sadržajno analiziraju navedeni postojeći radovi, uočava se raskorak između ranije objavljenih radova (Žiljak, 2006; Hill, 2010; Mataković, 2011; Petek, 2014b) i najrecentnijeg rada (Petković, 2017). Raniji radovi inicijalno definiraju koncept i studije, informiraju o njima te elementarno upućuju na supostojanje srodnih koncepata. S druge strane, najrecentnije objavljen tekst čitateljstvu pristupa kao već (dubinski) upoznatom sa studijama transfera i pripadajućim kategorijalnim aparatom. Čini se stoga kako je hrvatska znanstvena zajednica preskočila korak između upoznavanja s konceptom i njegovog razumijevanja. Namjera je ovog rada popuniti tu prazninu. ${ }^{4}$

Ovaj se rad može shvatiti kao historijat istraživanja prijenosa javnih politika između političkih djelokruga. Pored pregleda evolucije pristupa ponudit će se i izvorna sistematizacija i demarkacija različitih studija. Autorica se slaže s Davidom Bensonom i Andrewom Jordanom koji se, zazivajući uvide Giovannia Sartoria o opasnosti konceptualne rastezljivosti, zalažu za konsolidaciju studija transfera (Benson i Jordan, 2011; 2012). ${ }^{5}$ Ambicija je rada "donijeti korisnu konceptualnu

${ }^{3}$ Prema saznanju ove autorice ne postoji nijedan stariji hrvatski tekst koji se bavio konceptom transfera javnih politika iz politološke perspektive (nap. aut. časopis Političko obrazovanje nije dostupan na portalu Hrčak).

4 Istovremeno ovaj rad može se prepoznati i kao implicitan apel za većom aplikacijom tog istraživačkog okvira unutar hrvatske politološke zajednice.

5 Određeni autori zagovarat će veću interdisciplinarnost i labavije definiranje transfera (vidi Dussauge-Laguna, 2012; McCann i Ward, 2012). Ipak, najučestaliji je pristup, ako ne i uniformno proveden, razgraničenje ovih od ostalih studija. Potonji pristup nije motiviran željom za metodološkom i konceptualnom separacijom. Dapače, dominantna je tema ona o interdisciplinarnom dijalogu. 
klarifikaciju" (Petković, 2017: 764) te će se voditi sljedećim pitanjima: što je transfer javnih politika i u kakvom je odnosu s difuzijom, konvergencijom, izomorfizmom i izvođenjem pouka iz iskustva drugih? U paralelizmu s time postavlja se i pitanje: koje su sličnosti i razlike studija difuzije, konvergencije i transfera te putem kojih kriterija one mogu biti delimitirane? Na kraju postavljaju se i pitanja o izvornom kategorijalnom aparatu studija transfera, o odnosu tih studija s teorijama promjene javnih politika te njihovoj potencijalnoj evoluciji.

Rad započinje kratkim osvrtom na evoluciju određenja javnih politika s posebnim osvrtom na one elemente definicije koji su izazvali pojačan interes istraživača difuzije, konvergencije i transfera. Nakon toga prikazuje se nastanak i razvoj tih istraživanja, njihove prednosti i nedostaci te nude kriteriji njihovog razlikovanja. U trećem odjeljku podrobnije se analizira kategorijalni aparat studija transfera, a u posljednjem se te studije situira unutar širih teorija promjene javnih politika te nagoviješta njihov moguć razvoj. Zaključak ukratko sumira izneseno, ali i daje prijedloge za aplikaciju studija transfera na potencijalne istraživačke situacije.

\section{Ukratko o konceptualizaciji javnih politika}

Opće je mjesto da povijest poddiscipline javnih politika započinje sredinom 20. stoljeća pionirskim radom Harolda D. Lasswella. Originalna Lasswellova zamisao, pače apel, o restrukturiranju političke znanosti oko pojma javnih politika, primjenjujući načela multidisciplinarnosti, problemskog usmjerenja i normativnosti te posljedično nastanka znanosti javnih politika, samo je djelomično zaživjela. Desetljećima internog razvoja multidisciplinarnost je, ako ne zamijenjena, onda snažno nadopunjena metodologijskim i teorijskim ograničavanjem poddiscipline; problemsko usmjerenje često je, opravdano ili ne, napuštano zbog političkih nužnosti ili odnosa moći; a normativnost je naišla na zid višestruke složenosti i premreženosti političkih i društvenih problema te njihovih uzroka u (post)modernome svijetu (Fink-Hafner, 2011: 25; Grdešić, 1995: 10-11; Howlett i Ramesh, 1995: 2-4). Danas nećemo o istraživanju javnih politika govoriti kao o izdvojenoj znanosti. Čvrsto ustanovljena kao politologijska poddisciplina od svojih prvih (iako grandiozno zamišljenih) koraka, ta je orijentacija doživjela ubrzan i plodan razvoj. Dobro se to može ilustrirati i definicijskim pluralizmom svoje analitičke kategorije: javnih politika.

Kada govorimo o javnim politikama, u vidu imamo usmjerenost na "rješavanje sadržajnih problema politike, a ne na stjecanje političkog poborništva" (Petak, 2007: 188). Time činimo prvi korak prema razumijevanju i definiranju javnih politika. Započinjemo s onim što se najčešće spominje: javne politike se definiraju kao cjelovit skup odluka i tradicionalno pripisuju uz djelovanje vlade (Hague i dr., 2001: 409). Ta definicija jasno upućuje na razlikovanje između (sporadične, singu- 
larne) odluke i cijelog sustava (međusobno povezivih) odluka. Naime, proklamirani ciljevi nisu dostatni za definiciju javne politike, što je pak na tragu Hillove konstatacije da "na politike treba gledati kao na ono što se stvarno događa, a ne ono što političari kažu da će se dogoditi" (Hill, 2010: 17). Navedena definicija određuje i glavnog aktera (vladu) kojem dodjeljuje (pro)aktivnu funkciju. Također, ona implicira hijerarhiju i ciljnu racionalnost odlučivanja te etatizam.

Takvo određenje javnih politika višestruko je nadopunjeno teorijskim i praktičnim uvidima različitih autora. Ne ulazeći u detalje (vidi Grdešić, 1995: 17-19; Hill, 2010: 14-22; Howlett i Ramesh, 1995: 4-7; Petak, 2007: 187-192; Petek i Petković (ur.), 2014), za temu ovog rada važno je spomenuti diskusiju o promjeni prirode procesa stvaranja javnih politika i reperkusijama te promjene na određenje samih javnih politika. Sve se učestalije propituje sposobnost vlasti da samostalno djeluje, odlučuje i usmjerava ostale aktere. Kao možda najznačajniji aspekt javnih politika kako ih se konceptualizira za potrebe ovog rada jest pretpostavka o nemogućnosti ili nevoljkosti autohtonog djelovanja formalnih aktera zbog izmijenjenih okolnosti u modernom, globaliziranom svijetu.

Iako društveni znanstvenici teško, ukoliko uopće, postižu konsenzus o definiranju pojma globalizacije, temeljno je polazište ono o drastičnim promjenama uzrokovanim tehnološkim i komunikacijskim inovacijama, prekograničnim i prekooceanskim kretanjima kapitala te dostupnošću raznovrsnih kulturnih i inih sadržaja. Globalizacija nije nov fenomen, no ovu recentnu fazu obilježava zavidan opseg, složenost, brzina i jeftinoća (Keohane i Nye, 2000: 111-112). Istovremeno, ili baš zbog toga, dolazi do sve veće internacionalizacije političkih problema i pitanja poput migracija, borbe protiv korupcije, zaštite okoliša, očuvanja zdravlja i sl. Kako bi se ti problemi riješili, razvijaju se nove institucije i instrumenti. U drugoj polovici 20. stoljeća prepoznata je eksplozija osnivanja različitih međunarodnih institucija i sklapanja međunarodnih ugovora kao i eksponencijalan rast (međunarodnih) nevladinih organizacija. Važno je naglasiti kako globalizacija nije egalitarna. Zamjetne su diskrepancije u pristupu globalnoj areni, odnosno "globalnoj agori” kako ju naziva Diane Stone (2008: 21), te u odnosima moći sudionika (Cairney, 2012; FinkHafner, 2011; Hill, 2010; Keohane i Nye, 2000; Massey, 2009; Stone, 2008).

I unutar discipline javnih politika znanstvenici detektiraju i teoretiziraju te izmijenjene okolnosti i njihove implikacije. Za potrebe ovog rada čini se smislenim ukratko prikazati pomak od vladanja k javnom upravljanju utjelovljenom u konceptu višerazinskog upravljanja te koncept mreža javnih politika, poglavito u njegovoj recentnoj inkarnaciji: transnacionalnim zagovaračkim mrežama. Javno upravljanje odnosi se na nove prakse vladanja unutar kojih država gubi dominantnu ulogu (Lajh, 2007; Petak, 2014). Pritom se država sve više oslanja na neformalne aktere u ostvarivanju svojih funkcija. Riječ je o "difuziji autoriteta” (Hooghe i Marks, 2003: 
234), a epitet višerazinsko upućuje na smjer te difuzije koja se odigrava kroz više, bilo teritorijalnih bilo funkcionalnih, instanci (Hooghe i Marks, 2003; Hupe i Hill, 2006; Kustec Lipicer, 2007; Lajh, 2007; Petak, 2014).

Pritom ne treba prerano proglasiti smrt države - ona ostaje važan, a ovisno o vlastitoj moći u globalnoj areni i sve važniji igrač za nacionalne, regionalne i globalne javne politike (Fink-Hafner, 2011). Novost je pritom supostojanje novih oblika autoriteta usporedno s autoritetom države. Upravo u kontekstu postojanja drugih autoriteta i sve većeg oslanjanja na neformalne aktere promišljaju se i koncepti horizontalnih mreža ili zajednica javnih politika (Börzel, 1998; Sabatier, 1998), a koje se prepoznaju kao sve učestalije prekogranične i međunarodne (Keck i Sikkink, 1999; Stone, 2004; 2008; True, 2015). Transnacionalne zagovaračke mreže, kako ih nazivaju Margaret Keck i Kathryn Sikkink, ključni su akteri za iniciranje novih javnih politika i monitoring postojećih. Djeluju na međunarodnoj razini, strateški koristeći informacije kao ključni resurs (Keck i Sikkink, 1999). Pored takvih mreža pojavljuje se i nov profil aktera zaduženih za formulaciju i implementaciju politika: međunarodni službenici i birokrati, transnacionalni profesionalci za javne politike i globalni menadžeri (Stone, 2008). Kao što je vidljivo iz ovog kratkog prikaza, prošupljivanje države, koegzistencija mnogih međunarodnih režima te pojava novih ili rekonfiguracija starih aktera usložnjavaju i internacionaliziraju proces stvaranja javnih politika. Ti su uvidi u samoj srži transfera javnih politika i njegovog istraživanja.

\section{Transfer javnih politika i srodni koncepti}

Koncept studija transfera javnih politika je prijeporan. Ponekad se označava kao istraživački pristup ili okvir (Marsh i Sharman, 2009: 279), ponekad kao eksplanacijska teorija (Benson i Jordan, 2011), ponekad kao analitički pristup ili heuristički model (Petak, 2007: 197; Evans, 2017b: 25) procesa stvaranja javnih politika. Tim studijama snažnog multidisciplinarnog karaktera osporava se analitička preciznost (vidi James i Lodge, 2003; Hill, 2010: 173-175). Mark Evans sumira kritike u četiri glavne skupine: kako se analiza transfera javnih politika ne može razlikovati od normalnih procesa stvaranja javnih politika te racionalnih pristupa nastanku javnih politika; kako autori ne uspijevaju razviti eksplanacijsku teoriju razvoja javnih politika; kako ne postoje rigorozni alati kojima bi se moglo utvrditi je li došlo do transfera javnih politika; te kako takav tip istraživanja nije relevantan u praksi (Evans, 2009a: 238). Sličnu kritiku možemo pronaći i kod Hilla, koji ustvrđuje kako je taj pristup "pomalo [...] banalan" (Hill, 2010: 173). Recentnija kritika, iz interpretatističkog rakursa, može se naći u tekstu Eugenea McCanna i Kevina Warda. Autori smatraju kako su studije transfera previše usmjerene na aktere, a nedovoljno na šire određenje djelovanja; kako su previše nacionalne i previše racionalne te kako naglasak stavljaju na doslovan prijenos sadržaja javnih politika (McCann i Ward, 2012). 
Kao odgovor na takve prigovore, autori naklonjeni tom konceptu ulažu opsežne napore $u$ internu standardizaciju, filtriranje i izgradnju analitičkog i kategorijalnog aparata (vidi Benson i Jordan, 2012; Dolowitz i Marsh, 2012; Marsh i Evans, 2012). Jedan od ključnih razloga tzv. konceptualne neizbrušenosti nesumnjivo je kasni postanak, no i više od toga razlozi se mogu naći u multidisciplinarnom karakteru te supostojanju različitih preklapajućih pojmova čiji se zagovornici počesto nadmeću za primat. Pored transfera ovdje se radi o konceptima difuzije, izomorfizma i konvergencije (a implicite i divergencije), ${ }^{6}$ kojima se bave autori s područja međunarodnih odnosa, javnih politika, komparativne politike, (organizacijske) sociologije itd. (Evans i Davies, 1999: 361; Marsh i Sharman, 2009: 269).

Međusobno supsumiranje pojmova nije rijedak slučaj pa nailazimo na primjere autora koji smatraju da je transfer oblik difuzije (Newmark, 2002), da su konvergencija i difuzija oblici transfera (Evans, 2009b), ali i da su transfer i difuzija međusobno zamjenjivi koncepti (Mossberger, 2008). ${ }^{7}$ Po mišljenju iznesenom u ovom radu, a kao što je vidljivo i iz Tablice 1, međusobno je supsumiranje i zamjenjivanje koncepata nepotrebno jer svaki ima: različit analitički fokus (rezultat odnosno proces), koristi specifičnu metodologiju (studije velikog $\mathrm{N}$ odnosno malog $\mathrm{N}$ te kvantitativne odnosno kvalitativne metode) te se smješta u suprotstavljene metateorijske tabore (strukturalističke odnosno racionalističke). Koja su, dakle, preklapajuća mjesta, a koji izvorni doprinosi studija difuzije, konvergencije i transfera javnih politika?

Razvoj tih istraživanja započet je u Sjedinjenim Američkim Državama, unutar discipline komparativne politike, studijama difuzije šezdesetih godina prošlog stoljeća. Klasično djelo Everetta Rogersa uvelo je nove istraživačke preokupacije, a djelo Jacka L. Walkera ${ }^{8}$ postavilo je standarde budućih istraživanja. Hipoteze o ograničenoj racionalnosti, poduzetničkim i nepoduzetničkim državama te važnosti geografske blizine za širenje javnih politika i dalje su ključni lajtmotivi koncepta difuzije. U svojoj prvoj fazi studije difuzije fokusirale su se na širenje inovacija među američkim saveznim državama, ali i između savezne i federalne razine. U kasnijim

${ }^{6}$ Navedeni termini mogli su biti kroatizirani, no kako je hrvatski jezik usvojio ove oblike, a unutar poddiscipline ponuđeno je prijevodno usmjerenje (vidi Hill, 2010; Petek, 2014b), zadržani su bez promjena.

7 U već navedenim tekstovima o transferu objavljenim na hrvatskom također ne nailazimo na uniformnu podjelu i razgraničenje između studija difuzije, konvergencije i transfera iako se njihovo supostojanje u većini tekstova napominje (vidi Hill, 2010; Mataković, 2011; Petek, 2014b; Petković, 2017; Žiljak, 2006).

${ }^{8}$ Prvo djelo je knjiga Diffusion of Innovations objavljena 1962. godine, a potonje članak "The Diffusion of Innovations Among the American States" objavljen u časopisu American Political Science Review 1969. godine. Osim tih autora u okviru studija difuzije možemo spomenuti i Roberta Craina, Georgea Fielda, Thomasa Robertsona, Karen Mossberger itd. 
Tablica 1. Usporedba studija transfera, difuzije i konvergencije

\begin{tabular}{|l|c|c|c|}
\cline { 2 - 4 } \multicolumn{1}{c|}{} & \multicolumn{3}{c|}{ STUDIJE } \\
\cline { 2 - 4 } \multicolumn{1}{c|}{} & transfera & difuzije & konvergencije \\
\hline analitički fokus & proces & proces & rezultati \\
\hline metateorija & racionalistička & strukturalistička & strukturalistička \\
\hline metodologija & kvalitativna & kvantitativna & kvantitativna \\
\hline uzorak & mali & veliki & veliki \\
\hline
\end{tabular}

Napomena: Metateorijske obitelji sastavljene su od empirijskih teorija koje međusobno dijele fundamentalna gledišta, poput primata individue, strukture ili kulture u političkim procesima (Landman, 2008: 332-339; Marsh i Stoker, 2005: 280-281).

Izvor: Autorica.

fazama teritorijalni opseg istraživanja se proširuje, a značajan doprinos ostvaruje se na razini regionalnih komparativnih studija (Bulmer i dr., 2007: 4; Cairney, 2012; Dolowitz, 2017; Dolowitz i Marsh, 1996; Evans, 2009b: 244; Mossberger, 2008).

Kako se ne bi upalo u zamku samorazumljivosti, važno je definirati što se točno misli pod pojmom difuzija. David Marsh i Jason C. Sharman kao minimalističku definiciju difuzije navode da je to "proces kojim izbori javnih politika jedne zemlje utječu na izbor druge" (Marsh i Sharman, 2009: 270-271). Ono što takav tip minimalističke definicije implicira jest da izbor druge zemlje može biti divergencija u javnim politikama. Ipak, a napominju to i navedeni autori, to je rijedak slučaj u studijama difuzije koje kao rezultat gotovo isključivo pretpostavljaju konvergenciju javnih politika. Čini se stoga svrsishodnije difuziju definirati kao proces širenja ideja, javnih politika i inovacija iz jednog političkog djelokruga u drugi (Knill, 2005: 766; Mossberger, 2008: 1482; Newmark, 2002: 152).

Literatura o difuziji sugerira da javna politika curi ili prodire, kao nešto što je zarazno prije negoli odabrano. Podrazumijeva širenje, raspršivanje i rasprostiranje ideja ili praksi iz zajedničkog izvora ili točke polazišta (Stone, 2004: 546).

Iz navedenih definicija može se zaključiti da se studije difuzije fokusiraju na proces, dok ishod uzimaju kao zadan. U analizi tog procesa uobičajeno se koriste tri modela: organizacijski, koji promatra interakciju aktera i dinamiku širenja kroz mreže javnih politika; geografski ili regionalni, koji utvrđuje učinak zemljopisne blizine na preuzimanje javnih politika te deterministički, koji pokušava predvidjeti (ne)poduzetničke države (Newmark, 2002: 158-159). Glavnina istraživanja učinjena je ipak unutar posljednja dva modela, između ostalog i zbog dominantne metodologije i metateorijskog utemeljenja studija difuzije. Naime, većina autora unutar 
te tradicije pokazuje interes za utvrđivanje socioekonomskih i povijesnih obrazaca širenja, strukturalnih i geografskih uvjeta za difuziju te sekvencijsku klasifikaciju procesa (vidi Cairney, 2012). Christoph Knill ovako opisuje idealtipsku studiju difuzije: u prvom koraku opisuje se obrazac usvajanja neke inovacije javne politike, a zatim se analiziraju faktori koji doprinose uočenom procesu širenja (Knill, 2005: 766). Usmjerenost na pronalaženje obrazaca očituje se i u primijenjenoj metodologiji. Studije difuzije, uz rijetke iznimke, baziraju se na kvantitativnim metodama i velikim uzorcima - koje, iako omogućuju teorijske generalizacije, istovremeno zanemaruju finese specifičnih kulturnih razlika ili političkih dinamika (Dolowitz, 2017; Marsh i Sharman, 2009; Stone, 2001; 2004). ${ }^{9}$ Kao ilustrativan primjer sklonosti kvantitativnoj metodologiji, poopćivosti i prognostici može poslužiti i Indeks inovacije koji je osmislio Walker, a koji mu je poslužio za rangiranje američkih saveznih država s obzirom na njihov poduzetnički status (Mossberger, 2008: 1482).

Ono što se prepoznalo kao manjkavost difuzijskog pristupa - izostanak analize stvarnih sličnosti i potencijalnih razlika u rezultatima - usmjerilo je istraživače na novi tip studija: studije (međunarodne) konvergencije i izomorfizma. Studije konvergencije, potekle iz političke ekonomije, pojavljuju se u osamdesetim godinama prošlog stoljeća, ${ }^{10}$ a glavni procvat doživljavaju u devedesetim, ${ }^{11}$ što je pak izravno povezano sa značajnim porastom interesa za istraživanja globalizacije i europske integracije (Bennett, 1991: 215-216; Bulmer i dr., 2007: 4-5; Holzinger i Knill, 2005: 775). Konvergencija podrazumijeva "kretanje iz različitih pozicija prema nekoj zajedničkoj točci” (Bennett, 1991: 219) te ju možemo definirati kao

svako povećanje sličnosti jedne ili više karakteristika određene javne politike (...) tijekom danog vremena. Konvergencija javnih politika tako opisuje krajnji rezultat temporalnog procesa promjene usmjerenog zajedničkoj točci, neovisno o kauzalnim procesima (Knill, 2005: 768).

Ta definicija potvrđuje da su studije konvergencije primarno usmjerene na sličnost rezultata potencijalno različitih domaćih ili međunarodnih procesa i mehanizama. Na primjer, Katharina Holzinger i Knill identificiraju pet mehanizama putem kojih dolazi do konvergencije: nametanjem rješenja od strane druge države ili in-

9 Diane Stone zaključuje da su studije difuzije "opčinjene procesom i uvjetima" širenja nauštrb sadržaja novih javnih politika (Stone, 2004: 547), a David P. Dolowitz i Marsh difuziju su okarakterizirali kao "proces bez aktera" (Marsh i Sharman, 2009: 274).

${ }^{10}$ Kao referentno djelo možemo spomenuti knjigu The Future of Industrial Societies: Convergence or Continuing Diversity? Clarka Kerra objavljenu 1983. godine.

11 Članak Colina Bennetta (1991) može se shvatiti polazištem te ključnim djelom studija konvergencije. Osim njega mogu se spomenuti i autori poput Knilla, Holzinger, Christophera Pollitta itd. 
stitucije, međunarodnim usklađivanjem, regulatornim natjecanjem, međunarodnom komunikacijom te neovisnim rješavanjem problema (Holzinger i Knill, 2005: 786792). No, kao i u slučaju studija difuzije, postoji dominantna preokupacija istraživača i to međunarodnim faktorima kao uzrocima konvergencije. To se može vidjeti i iz netom navedene podjele u kojoj je samo jedan od mehanizama autonoman (Marsh i Sharman, 2009: 271). U prvoj fazi razvoja studija glavnina fokusa bila je usmjerena na procese industrijalizacije i modernizacije. Autori poput Harolda Wilenskog, Phillipsa Cutrighta, Henrya Aarona i Frederica Pryora smatrali su da visoka razina industrijskog razvoja i društvenog bogatstva države rezultira sličnim društvenim problemima i mogućnostima te da će države, neovisno o svojoj političkoj i/ili socijalnoj strukturi, odabrati slična rješenja.

Recentnije, fokus se pomiče na procese globalizacije i regionalizacije. Iako se u toj drugoj fazi više pozornosti usmjerava na mehanizme i djelovanje aktera, te su studije i dalje primarno strukturalističke, a istraživanja se provode na makrorazini. $\mathrm{Na}$ taj način studije difuzije i studije konvergencije pokazuju se kao lice i naličje istog metodološkog i metateorijskog novčića (Bennett, 1991; Bulmer i dr., 2007: 12; Howlett i Ramesh, 1995: 106-107; Stone, 2001). ${ }^{12}$ Izomorfizam je pritom koncept koji je najuže povezan s konvergencijom. Pače, jedino je razlikovanje u empirijskom fokusu izomorfizma, koji je na organizacijskim strukturama odnosno na organizacijskoj analizi (Holzinger i Knill, 2005: 779; Radaelli, 2000). ${ }^{13}$ Te studije razvijene su unutar discipline sociologije organizacije te istražuju povećanje sličnosti u institucionalnim i organizacijskim strukturama i kulturama (Knill, 2005: 768). To čini ključnu konceptualnu i analitičku razliku u odnosu na dosad spomenute studije, ali i posljednju preostalu: transfer javnih politika.

Studije transfera javnih politika prate isti razvojni put kao i studije konvergencije. Iako se upućivanje na komparaciju i izvođenje pouka iz tuđih političkih ustroja može pronaći još u Aristotelovoj Nikomahovoj etici (Evans, 2009a: 237), studiozni tekstovi u okviru tog pristupa javljaju se od devedesetih godina prošlog stoljeća naovamo. Taj razvoj zbiva se kao odgovor na usložnjavanje političkih realnosti te percipirane manjkavosti dotadašnjih smjerova istraživanja. Naime, kraj 20. stoljeća bilježi snažan porast pojavljivanja transfera javnih politika: tehnološki napredak ubrzava prekograničnu i globalnu komunikaciju, međunarodne organizacije postaju

12 Ilustrativan primjer terminološke konfuzije može se pronaći i u posebnom broju Journal of European Public Policy posvećenom konvergenciji javnih politika objavljenom 2005. godine. Unatoč pokušaju samog urednika Knilla da tipologizira različite koncepte i konvergenciju razgraniči od transfera i difuzije, u svome komentaru Jordan uočava da dio priloga potpada pod studije konvergencije, no drugi je dio priloga de facto srodniji studijama difuzije (Jordan, 2005: 947).

13 Vidi npr. produkciju Paula J. DiMaggia i Waltera W. Powella. 
sve važniji akteri pri stvaranju javnih politika, a globalna ekonomija čvrsto uokviruje političke procese (Dolowitz i Marsh, 2000: 6-7). U takvim okolnostima sve je izraženiji interes istraživača za detektiranje konkretnih mehanizama i aktera kojima se šire i prenose javne politike. Takvu analizu nije bilo moguće provesti studijama difuzije, koje traže uzorke širenja, ili studijama konvergencije, koje se fokusiraju na rezultate. Stoga se razvijaju studije transfera koje "koriste forenzičku metodu analize pri identificiranju vanjskih katalizatora promjene, ključnih aktera, njihovih motiva te procesa prijenosa javnih politika iz jednog u drugi djelokrug" (Bulmer i dr., 2007: 5). Najčešće se koristi i citira definicija transfera kao

procesa u kojem se znanje o javnim politikama, administrativnim aranžmanima, institucijama itd. u jednom vremenu i/ili mjestu koristi u razvoju javnih politika, administrativnih aranžmana i institucija u drugom vremenu i/ili mjestu (Dolowitz i Marsh, 1996: 344). ${ }^{14}$

Iako ta definicija sugerira iznimnu važnost kognitivnog i racionalnog aspekta stvaranja javnih politika, tzv. znanje o ne bi se trebalo precijeniti. Racionalnost može biti ograničena, pa i do te mjere manjkava da rezultira propašću javne politike, a može se i zaobići prisilnim ili nametnutim transferom. Uostalom, postoje i višestruki objekti transfera (poput ideologije, institucija, instrumenata itd.). Zbog svega toga transfer javnih politika ne bi se trebao promatrati isključivo kroz prizmu transfera znanja, a naročito ne onog dobrovoljnog. Definicija nas upućuje i na procesni fokus studija transfera - po čemu su slične studijama difuzije. Međutim, a kao specifična razlika u odnosu na dosad spomenute studije, za taj je pristup karakteristično istraživanje aktera, njihovih motivacija te detekcija specifičnih mehanizama prijenosa i usvajanja javnih politika. Pritom se prvenstveno koriste kvalitativne metode i mali uzorci (dominantne su studije slučaja). Studije transfera tako se razotkrivaju kao mezorazinska i mikrorazinska istraživanja dominantno ${ }^{15}$ racionalističkog tipa (Bulmer i dr., 2007: 14; Dolowitz, 2017: 39; Marsh i Sharman, 2009). Spomenimo pritom kako većinu autora koji produciraju u okviru studija transfera možemo smjestiti u fundacionalistički ontološki te pozitivistički i kritičko realistički epistemološki tabor (Dolowitz i Marsh, 2012: 344; Marsh i Evans, 2012a: 481).

${ }^{14}$ Dolowitz i Marsh i dalje su referentni autori unutar tog pristupa, a njihov tekst "Who learns what from whom: A review of the policy transfer literature" polazišna je točka promišljanja o transferu javnih politika (Dolowitz i Marsh, 1996). Pored navedenih uz te studije povezujemo autore poput Evansa, Stone, Simona Bulmera, Jonathana Daviesa itd.

${ }^{15}$ Treba napomenuti da većina autora u sklopu tog pristupa ne isključuje važnost strukture, no uzimaju je kao datost, pozadinsku varijablu, što navodi autore Marsha i Sharmana da apeliraju za većom dinamičnošću u istraživanju, odnosno za definiranjem i istraživanjem tih odnosa kao dijalektičkih (Marsh i Sharman, 2009). 
Slika 1. Tipologija javnih politika s obzirom na profil procesa i rezultate

PROCES

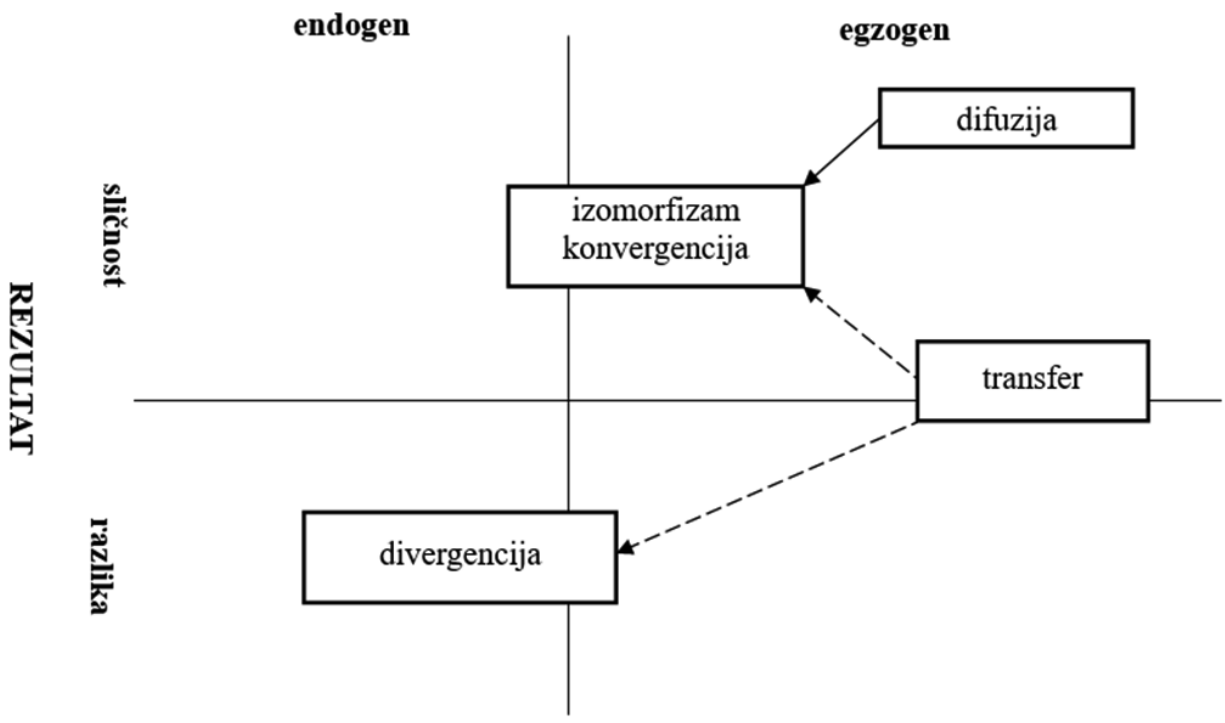

Legenda: $\longrightarrow$ snažnija povezanost

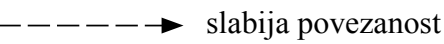

Slika 1 prikazuje temeljne koncepte navedenih studija u dinamičnom odnosu. Kao što je prethodno rečeno, difuzija i transfer se prvenstveno odnose na procese - $\mathrm{i}$ to izvana potaknute ili egzogene procese. Istraživači difuziju gotovo izjednačavaju s konvergencijom, odnosno difuziji pripisuju povećanje sličnosti javnih politika. S druge strane, istraživanja transfera ostavljaju mogućnost i za odustajanje od prijenosa ili za nastanak konačnog rješenja koje će biti odmak od inicijalnog. Time transfer može rezultirati i divergencijom javnih politika. Ipak, primarni je fokus i tih istraživača na konvergenciji, što je shematski vidljivo i u udaljenosti tipoloških kućica. Konvergencija, i njezin organizacijski pandan izomorfizam, opisuju krajnji rezultat koji je definiran kao sličnost, dok divergencija opisuje dijametralno suprotan slučaj. Kao objašnjenja konačnih rezultata, ti koncepti ostaju otvoreni za empirijsku provjeru kauzalnosti odnosno endogenosti ili egzogenosti procesa koji ih proizvode. Ipak, većina istraživača prvenstveno će konvergenciju objašnjavati izvanjski potaknutim procesima, a divergenciju endogenim procesima stvaranja javnih politika. 


\section{Modeli transfera javnih politika}

Mogu se razlikovati oblici transfera s obzirom na uzroke te s obzirom na rezultat i uspjeh usvajanja javnih politika, a koji se međusobno mogu kombinirati u različitim varijantama. Te podjele možemo razumjeti kao ulaznu i izlaznu stranu procesa transfera: $\mathrm{s}$ jedne strane, podstrek, motivacija ili razlog zbog kojeg do njega dolazi, a s druge, način, rezultat $i$ uspješnost njegove provedbe. Izgradnju svog kategorijalnog aparata Dolowitz i Marsh započinju sadržajnom kritičkom revalorizacijom, ali de facto terminološkom asimilacijom Bennetta i Richarda Rosea (Bulmer i dr., 2007: 14; Dolowitz i Marsh, 1996: 346-351; Evans i Davies, 1999: 363; vidi i Bennet, 1991; Rose, 1993). Izvođenje pouka iz prakse drugih (lesson drawing), pristup koji se primarno veže uz znanstvenu produkciju Rosea, možda je najsrodniji transferu javnih politika od svih dosad spomenutih pristupa. Studija transfera počiva na nekim njegovim postavkama, no istovremeno i na njegovim kritikama. Od potonjih Dolowitz navodi preveliko oslanjanje na model racionalnog aktera te voluntarizam u izvođenju pouka (Dolowitz, 2017: 38). Transfer javnih politika, za razliku od izvođenja pouka, počiva na pretpostavci da se "interakcije odvijaju između aktera koji imaju nejednaku moć" (ibid.: 39).

Iako u svojem originalnom tekstu Dolowitz i Marsh navode tri stupnja transfera, naknadno ih počinju tretirati kao točke unutar kontinuuma (usp. Dolowitz i Marsh, 1996 s Dolowitz i Marsh, 2000). Po njima, politička je realnost kompleksna mješavina utjecaja i interakcija koja oscilira između polova čiste (endogene) racionalnosti i izravne (egzogene) prisile. Između tih suprotstavljenih, gotovo idealnih polova javljaju se različiti oblici i stupnjevi uvjetovanja, poput ograničene racionalnosti, percepcija, obveza i/ili međunarodnih pritisaka. Pritom je zadatak istraživača prepoznati konkretne mehanizme u svakom specifičnom slučaju, ali i u svakoj fazi specifičnog slučaja. Naime, motivacije aktera, ionako heterogene, kao i politički kontekst mijenjaju se kroz vrijeme - što uvjetuje i promjene u transferu. Kontinuum omogućava neprekidno mapiranje tih fluidnih procesa te podsjeća istraživača na nužnost longitudinalnog promatranja (Dolowitz i Marsh, 2000: 16-17). Iako su autori nesumnjivo u pravu kada o političkoj realnosti pišu kao o heterogenoj, kompleksnoj pa i proturječnoj pojavi, za analitičke potrebe čini se svrsishodno taj kontinuum sažeti u četiri idealtipska stupnja transfera prikazana u Tablici 2.

U najudaljenijim ćelijama nalaze se najrjeđi oblici, oni koje bi se na kontinuumu svrstalo u savršene polove. Dakle, s jedne strane to je izravno prisilni transfer (directly coercive transfer) čiji se primjeri nalaze u prošlosti kao rezultat kolonizacije ili ratne pobjede. Situacija je to u kojoj jedna vlada uspijeva nametnuti drugoj javne politike i institucionalna rješenja. To je odnos potpune nadmoći jedne nad drugom stranom u kojoj podčinjena nema alternative nego prihvatiti nametnuto. 
Tablica 2. Tipologija transfera javnih politika s obzirom na uzrok

\begin{tabular}{|c|c|c|c|}
\hline \multicolumn{2}{|c|}{ dobrovoljnost } & \multicolumn{2}{|c|}{ prisila } \\
\hline potpuna & ograničena & neizravna & izravna \\
\hline $\begin{array}{c}\text { problemski } \\
\text { orijentirano racionalno } \\
\text { izvođenje pouka } \\
\text { (npr. transfer } \\
\text { institucije } \\
\text { pravobranitelja) }\end{array}$ & \begin{tabular}{|} 
ograničena \\
racionalnost, želja \\
za prihvaćanjem, \\
regulatorna \\
kompeticija \\
(npr. utrka prema dnu)
\end{tabular} & $\begin{array}{l}\text { tzv. uzmi ili ostavi } \\
\text { (npr. članstvo u EU, } \\
\text { uvjeti pristupanja EU, } \\
\text { uvjeti IMF-a i WB-a) }\end{array}$ & $\begin{array}{l}\text { tzv. uzmi ili nestani } \\
\text { (npr. kolonizacija, } \\
\text { nametanje } \\
\text { institucionalnih } \\
\text { rješenja nakon poraza } \\
\text { u II. svj. ratu) }\end{array}$ \\
\hline
\end{tabular}

Izvor: Autorica, prilagođeno prema Bulmer i dr., 2007; Dolowitz i Marsh, 1996, 2000.

$\mathrm{Na}$ drugom je polu situacija savršene racionalnosti i potpunog voluntarizma. Vlada je u potpunosti autonomna u svom djelovanju te ciljno racionalno pristupa rješavanju problema. Takav potpuno dobrovoljan transfer (completely voluntary transfer) najuže je povezan s Roseovim konceptom izvođenjem pouka iz iskustva drugih, gdje ne postoji nikakva prisila, ni percipirana ni stvarna, na usvajanje neke javne politike. Primjere tog stupnja transfera teško je naći jer je upitno koliko je problemska orijentacija utemeljena u realnosti, a koliko u percepciji realnog. Isto tako upitno je i koliko su rješenja promišljena, akteri razboriti, a informacije dostupne i objektivne - općenito, graniči li ideja savršene racionalnosti s mitološkim. Upravo stoga mnogi autori optiraju za koncept ograničene racionalnosti aktera, što dovodi do dva najčešća, tzv. mješovita tipa transfera (prikazana u središnjim ćelijama Tablice 2).

Ograničeno dobrovoljni transfer (incompletely voluntary transfer) je tip koji obuhvaća dijapazon mogućnosti. U rasponu od više prema manje dobrovoljnim može se govoriti o transferu u kontekstu nesavršene informiranosti odnosno ograničene racionalnosti, transferu zbog percipirane nužde odnosno želje za međunarodnim prihvaćanjem te transferu kao rezultatu međunarodnog regulatornog natjecanja. ${ }^{16}$ Ključna značajka tog tipa jest percepcija - uvjetovanost je samonametnuta. To nije slučaj sa sljedećim tipom: neizravno prisilnim transferom (indirectly coercive transfer), gdje su uvjeti izvanjski nametnuti i jasnije zrcale odnose moći. Iako se i unutar tog tipa transfera mogu prepoznati različiti stupnjevi, najvažnija je distink-

16 Takav transfer tipičan je u području ekonomskih politika. U globaliziranom svijetu gdje se razvijene države bore za tržišta, a nerazvijene za investicije u industrijsku proizvodnju takvom se transferu pripisuje snižavanje cijene manualnog rada te smanjivanje države blagostanja, tzv. utrka prema dnu. 
cija ona između članica i nečlanica određenog međunarodnog režima. Članstvom se priskrbljuju veća prava sudjelovanja u stvaranju javnih politika na nadnacionalnoj razini, ali ono snažno obvezuje na njihovo preuzimanje na nacionalnoj razini - ugovorni transfer (obligated transfer). S druge strane, iako nečlanice nemaju mogućnost propitivanja postojećih nadnacionalnih javnih politika, u bilo kojem trenutku mogu odbiti pristupno uvjetovanje - uvjetovani transfer (conditioned transfer) (Bulmer i dr., 2007; Dolowitz, 2009; Dolowitz i Marsh, 1996; 2000).

U vrijeme mnogostrukih i razgranatih međunarodnih režima može se ustvrditi da je taj tip transfera najčešći: odvija se u okviru Europske unije, Međunarodnog monetarnog fonda, Ujedinjenih naroda itd. Specifična razlika između neizravnog i izravnog prisilnog transfera, a čiji se odjek može prepoznati i u razlici između ugovornog i uvjetovanog neizravnog transfera, jednostavno se može opisati razlikom između prava i sile. Države imaju pravo odbiti uvjete koji im se nameću, mogu odlučiti ostati izvan nekog međunarodnog režima. Ipak, to je formalistička distinkcija. Stvarna potreba i stvarni odnosi moći konstruiraju političke realnosti koje se nužno ne odražavaju u pravu - kao ilustrativan primjer mogu poslužiti uvjeti kreditiranja koje Međunarodni monetarni fond nameće, a nerazvijene zemlje iz nužde prihvaćaju (Bulmer i dr., 2007; Dolowitz, 2009; Dolowitz i Marsh, 1996; 2000).

Preuzimanje tuđih rješenja, bez obzira na razloge, ne znači nužno i identičnost sadržaja javnih politika. Razlike u motivaciji aktera, važnosti problema, odnosima političkih snaga, političkom i ekonomskom kontekstu, pa čak i formalnoj proceduri mogu rezultirati značajnim odmakom (ponekad i odustajanjem) od promatranog originala. Osim tih kontekstualnih i proceduralnih čimbenika, diskrepanciji doprinosi i opseg prijenosa odnosno odluka koji će se točno objekti preuzeti. Naime, preuzeti se mogu ne samo sadržaji javnih politika u smislu zakona, odredbi ili programa već i ciljevi i strukture, instrumenti i administrativne tehnike, institucije, ideologija, ideje i vrijednosti, pa čak i negativne lekcije (Dolowitz i Marsh, 1996: 349-350). Sve navedeno uvjetuje i tip transfera s obzirom na rezultat. Iako pri određenju tih tipova postoji određena razina terminološke konfuzije, možemo govoriti o dominantnim temama i terminologiji preuzetoj od Rosea (vidi Tablicu 3). U ovome radu koristi se Evansova klasifikacija uz manju terminološku i konceptualnu dopunu Bulmera, Dolowitza, Petera Humphreysa i Stephena Padgetta.

Najopsežniji oblik transfera tog tipa opisuje se kao preslikavanje (copying). To je situacija kada se preuzima postojeća javna politika iz drugog političkog djelokruga bez ikakvih promjena, a njen najočitiji dokaz je u identičnom formuliranju zakona, programa itd. Takav tip transfera je automatski i nerefleksivan, a velika je vjerojatnost da će njegov konačni ishod, naročito ako se transfer događa između heterogenih političkih djelokruga, biti neuspjeh javnih politika. Treba napomenuti da izravni prisilni transfer uvijek rezultira preslikavanjem. Oponašanje (emulation) 
Tablica 3. Razlike i sličnosti u terminologiji

\begin{tabular}{|c|c|c|c|c|c|}
\hline Bennett & $\begin{array}{c}\text { Bulmer / } \\
\text { Dolowitz / } \\
\text { Humphreys / } \\
\text { Padgett }\end{array}$ & $\begin{array}{c}\text { Dolowitz / } \\
\text { Marsh }\end{array}$ & Evans & Rose & Stone \\
\hline $\begin{array}{l}\text { 1. oponašanje } \\
\text { (emulation) } \\
\text { 2. umrežava- } \\
\text { nje elita i za- } \\
\text { jednica javnih } \\
\text { politika (elite } \\
\text { networking } \\
\text { and policy } \\
\text { communities) } \\
\text { 3. usklađiva- } \\
\text { nje (harmoni- } \\
\text { zation) } \\
\text { 4. prodiranje } \\
\text { (penetration) }\end{array}$ & $\begin{array}{l}\text { 1. oponašanje } \\
\text { (emulation) } \\
\text { 2. udruživanje } \\
\text { (synthesis) } \\
\text { 3. utjecanje } \\
\text { (influence) } \\
\text { 4. kočenje } \\
\text { (abortive) }\end{array}$ & $\begin{array}{l}\text { 1. preslikava- } \\
\text { nje (copying) } \\
\text { 2. oponašanje } \\
\text { (emulation) } \\
\text { 3. dodavanje } \\
\text { (mixtures) } \\
\text { 4. nadahnjiva- } \\
\text { nje (inspira- } \\
\text { tion) }\end{array}$ & $\begin{array}{l}\text { 1. preslikava- } \\
\text { nje (copying) } \\
\text { 2. oponašanje } \\
\text { (emulation) } \\
\text { 3. miješanje } \\
\text { (hybridiza- } \\
\text { tion) } \\
\text { 4. nadahnjiva- } \\
\text { nje (inspira- } \\
\text { tion) }\end{array}$ & $\begin{array}{l}\text { 1. preslikava- } \\
\text { nje (copying) } \\
\text { 2. prilagođa- } \\
\text { vanje (adap- } \\
\text { tation) } \\
\text { 3. spajanje } \\
\text { u mješavinu } \\
\text { (making } \\
\text { a hybrid) } \\
\text { 4. udruživanje } \\
\text { (synthesis) } \\
\text { 5. nadahnjiva- } \\
\text { nje (inspira- } \\
\text { tion) }\end{array}$ & $\begin{array}{l}\text { 1. idejni } \\
\text { (ideational) } \\
\text { 2. institucijski } \\
\text { (institutional) } \\
\text { 3. mrežni } \\
\text { (networks) }\end{array}$ \\
\hline
\end{tabular}

Napomena: Bennett je ključan autor literature o konvergenciji, Rose literature o izvođenju pouka iz prakse drugih, a ostali autori literature o transferu. Većina prikazanih autora razlikuje tipove s obzirom na konačni rezultat. Uočljiva je razlika u klasifikaciji Bennetta, koji prvi tip definira rezultatom, drugi akterima, a posljednja dva razinom prisile. Dodatno se ističe i Stone, koja pokušava objediniti različite klasifikacije iz rakursa dominantnih aktera.

Izvor: Autorica prema Bennett, 1991; Bulmer i dr., 2007; Dolowitz i Marsh, 2000; Evans, 2009b; Rose, 1993; Stone, 2004.

događa se kada se javnopolitička rješenja iz drugih djelokruga ne preuzimaju u potpunosti, već kontekstualno prilagođavaju. Dakle, određena strana javna politika smatra se uzornim rješenjem te služi kao polazišna točka u procesu, a pretpostavka je da će konačni rezultat biti (barem suptilna) nadogradnja i unapređenje izvorne javne politike. Prilikom miješanja (hybridization) dolazi do kombiniranja odnosno sinteze elemenata nekoliko različitih javnih politika iz različitih djelokruga kako bi se stvorio najprikladniji oblik za percipirane potrebe. Naglasimo kako je to najtipičniji oblik transfera. Nadahnjivanje (inspiration) izuzetno je slab oblik transfera te podrazumijeva tuđe rješenje kao inspiraciju - određena ideja nadahnjuje nova promišljanja o postojećem problemu i potiče stvaranje novih javnih politika. Dakle, ideja služi kao kreativni stimulans za nastanak nove javne politike, no institucionalni dizajn nadogradnja je postojećeg domaćeg rješenja ili pak nastaje ab ovo. Na kraju, kočenje transfera (abortive transfer), oblik koji predlažu autori Bulmer, Dolowitz, Humphreys i Padgett, opisuje situaciju u kojoj jednom započet transfer blo- 
kiraju veto akteri (Bulmer i dr., 2007: 17; Evans, 2009b: 245-246; vidi i Dolowitz i Marsh, 1996: 351; Marsh i Sharman, 2009: 271-272; Newmark, 2002: 156).

Osvrnimo se i na posljednju klasifikaciju - onu s obzirom na (ne)uspjeh. Autori Dolowitz i Marsh smatraju da je pitanje uspješnosti transfera jedno od ključnih unutar studija te da bi mu trebalo posvećivati više analitičke pažnje. U pokušaju unapređenja takvih istraživanja nude sljedeću klasifikaciju (Dolowitz i Marsh, 2000: 17; vidi i Stone, 2001: 9):

a) neupućeni transfer (uninformed transfer) događa se kada se javna politika importira bez (dovoljno) znanja o načinu njenog stvarnog funkcioniranja;

b) nepotpuni transfer (incomplete transfer) rezultat je djelomičnog prijenosa kojim se ne mogu ostvariti puni učinci javne politike; a

c) neprimjereni transfer (inappropriate transfer) onaj je koji ne uzima u obzir specifične političke, ekonomske i/ili socijalne razlike između političkih djelokruga u sklopu kojih se događa transfer.

Jedno od ključnih pitanja u okviru istraživanja transfera javnih politika jest: tko su akteri transfera? U svrhu što preciznijeg određenja njihove motivacijske logike i strategija, transfer javnih politika treba povezati s fazama procesa stvaranja javnih politika. Iako različiti autori taj proces različito sekvencioniraju (vidi Grdešić, 1995; Hague i dr., 2001; Hill, 2010; Howlett i Ramesh, 1995; Hupe i Hill, 2006; Petak, 2007; Petek i Petković, ur., 2014), uvriježena je podjela procesa stvaranja javnih politika na pet faza: fazu inicijative odnosno postavljanja na dnevni red, fazu formulacije odnosno izbora rješenja, fazu odlučivanja, fazu implementacije odnosno provođenja te fazu evaluacije odnosno vrednovanja javne politike. Te se faze razlikuju s obzirom na ciljeve, dinamiku i ključne aktere koji u njima sudjeluju.

Važno je napomenuti da se transfer javnih politika može odigrati u bilo kojoj od tih faza. Dapače, Dolowitz i Marsh naglašavaju kako će se različiti tipovi transfera realizirati ne samo s obzirom na različite oblike javnih politika koje se prenose ili involvirane aktere već i s obzirom na trenutak prijenosa u konkretnom procesu stvaranja javnih politika (Dolowitz i Marsh, 2000: 13). Istovremeno Dolowitz i Marsh identificiraju izabrane dužnosnike, političke stranke, birokrate odnosno državne službenike, grupe za pritisak, javnopolitičke poduzetnike i stručnjake, transnacionalne korporacije, institute za intelektualne usluge, nadnacionalne vladine i nevladine institucije te savjetnike kao glavne kategorije aktera u procesu transfera javnih politika (Dolowitz i Marsh, 1996; 2000). Ostali autori koji koriste taj okvir prepoznali su u svojim istraživanjima da su bitne i transnacionalne zagovaračke mreže te epistemičke zajednice (Stone, 2004; 2008). Na primjer, kao što je već spomenuto, Stone klasificira modele transfera s obzirom na aktere. Prema njoj su glavni akteri idejnog transfera instituti za intelektualne usluge, stručnjaci i profesio- 
nalne organizacije, institucionalnog transfera političari te (međunarodni) državni službenici i birokrati, a transfera putem mreža javnih politika nevladine organizacije, civilno društvo te državne i međunarodne agencije (Stone, 2004).

Takve podjele ipak ne treba slijepo slijediti jer je "identifikacija aktera u procesu stvaranja javnih politika i relativna važnost njihovih uloga empirijsko pitanje koje se ne može razriješiti a priori" (Howlett i Ramesh, 1995: 52). Evans i Davies aktere nazivaju agentima transfera te razvijaju koncept mreže transfera javnih politika kao "ad hoc struktura usmjerenih na djelovanje te uspostavljenih sa specifičnom namjerom ostvarivanja brze promjene javnih politika" (Evans, 2017b: 22). Autori su razvili taj koncept kako bi stekli uvid u višerazinsku i interaktivnu narav procesa transfera (Evans, 2017b; vidi i Evans, 2009b; Evans i Davies, 1999). Slično viđenje vidljivo je i u apelu Marsha i Sharmana za snažnijim analizama "interakcija između strukture i djelovanja tijekom vremena" uz primjenu morfogenetskog ciklusa Margaret Archer (Marsh i Sharman, 2009: 275; za morfogenetski ciklus vidi Marsh i Stoker, 2005: 281-285). I u tom radu zastupa se mišljenje kako je dijalektički pristup daleko produktivniji od metateorijske isključivosti: struktura omeđuje djelovanje, no djelovanje mijenja strukturu. Takav pristup zahtijeva i dodatno potvrđuje važnost dijakronične analize.

Navedeni apeli i inovacije počivaju na refleksivnim uvidima o postignutom razvoju studija te prepoznatim dominantnim istraživačkim preokupacijama - i njihovim manjkavostima. Unatoč tome što je raspon istraživanih sektorskih politika bio širok (za popis studija vidi Benson i Jordan, 2011; Dolowitz, 2017), u prvoj fazi okvir se primarno primjenjivao za detekciju transfera između država i to, kao što napominje Evans, između razvijenih država (Evans, 2017b: 12; vidi i Cairney, 2012: 251). Istraživanja su počivala na pretpostavkama o bilateralnim odnosima te se, čak i prigodom aplikacije okvira na utjecaj međunarodnih organizacija, promatrao njihov utjecaj na nacionalne države. Primjerice, $u$ okviru škole europeizacije dominantna je tema bila istraživanje harmonizacije nacionalnog zakonodavstva $\mathrm{s}$ pravnom stečevinom Europske unije (Benson i Jordan, 2011; Stone, 2004).

Upravo je takvo stanje discipline zazivalo ranije spomenute kritike zbog "metodološkog nacionalizma" studija transfera (Stone, 2004: 549). Ipak, u posljednjih desetak godina dolazi do veće heterogenosti u preokupacijama istraživača te do raznorodnije aplikacije modela transfera. Benson i Jordan nesumnjivo su na pravom tragu kada primjećuju da se takav razvoj dijelom može zahvaliti i priljevu novih istraživača raznorodnijih epistemoloških i metodoloških utemeljenja (Benson i Jordan, 2011: 372). Tako, između ostalog, možemo spomenuti i veći interes za pitanja transfera ideja, paralelnog transfera koji zaobilazi centre autoriteta, transfere iz globalnih financijskih institucija i sl. (Benson i Jordan, 2011; Evans, 2017b; 2018). Pritom istraživači sve češće kombiniraju studije transfera s ostalim pristupima koji pojašnjavaju promjene javnih politika. 


\section{Teorije promjene javnih politika: a što s transferom?}

Promjena je lice, a stabilnost naličje dinamike javnih politika. No promjena javnih politika raznorodno se definira i operacionalizira. Učestalo se to imenuje problemom promjene kao ovisne varijable (vidi Capano, 2009; 2013; Howlett i Cashore, 2009; Real-Dato, 2009). Taj problem nastaje stoga što se mijenjati mogu različiti elementi javnih politika, a promatranjem samo jednog elementa mogu se donijeti pogrešni zaključci o opsegu i važnosti promjene. Istovremeno promjena se odvija kroz vrijeme - ovisno o promatranom razdoblju promjena se može ili ne mora detektirati, a za promjenu je važna i brzina odnosno tempo. No pogrešno je pretpostaviti kako su radikalne promjene istoznačne s brzinom, a inkrementalne sa sporošću promjene. Uz pojam značajne promjene uobičajeno se povezuje nekoliko paradigmatskih ${ }^{17}$ teorija: isprekidana ravnoteža, zagovaračke koalicije ili tok javnih politika (vidi Petek, 2014a; Stachowiak, 2013).

Gdje se u sklopu tih sveobuhvatnih, paradigmatskih teorija promjene javnih politika mogu smjestiti studije transfera? Iako je pojam učenja o javnim politikama ili izvođenja pouka implicitan u mnogim od tih pristupa, same studije transfera nemaju rang paradigmatske teorije promjene. Proizlazi to i iz aspiracije samih autora. Naime, osim nekolicine ranije spomenutih autora koji transfer javnih politika opisuju kao teorijski pristup, tipično je viđenje manje ambiciozno. ${ }^{18}$ Dapače, sami pokretači pristupa Dolowitz i Marsh opisuju studije transfera kao okvir, koncept i heuristiku (Dolowitz i Marsh, 2012; Marsh i Evans, 2012b). Upravo stoga one se čine posebno kompatibilnima s drugim teorijskim okvirima. Primjerice s teorijama toka javnih politika i zagovaračkih koalicija (Dolowitz, 2017: 42-45), ali i javnog upravljanja (Benson i Jordan, 2011: 374; Marsh i Evans, 2012b: 588). Paul Cairney zagovara upravo taj pristup: povezivanje transfera javnih politika sa širom literaturom o promjenama javnih politika, koji (pristup) uključuje kombiniranje s konceptima inkrementalizma, višerazinskog upravljanja, isprekidane ravnoteže, tokova javnih politika i zagovaračkih koalicija (Cairney, 2012: 260-263), a sve kako bi se "razvile višestruke teorije" (ibid.: 264).

Učenje o javnim politikama čini se ipak najčešćim teorijskim lajtmotivom kada se govori o transferu javnih politika. José Real-Dato zasigurno je u pravu kada tvrdi kako se učenje o javnim politikama "može iskoristiti za učvršćivanje statusa

17 Sarah Stachowiak ih naziva globalnim teorijama (Stachowiak, 2013), a autori Howlett i Ramesh razlikuju između normalnih i paradigmatskih promjena javnih politika. Uvjetovanost prošlim razvojem i izvođenje pouka smještaju u kategoriju normalnog razvoja javnih politika (Howlett i Ramesh, 1995: 193-194).

18 Stoga i Hillovu kritiku da se razvoj "teorija transfera javnih politika može [...] promatrati s određenom skepsom" (2010: 174) - treba promatrati s određenom skepsom. Pa i zaključiti da je promašena: pošto razvoj teorije nije intencija većine istraživača. 
quo" (Real-Dato, 2009: 127). Isto bi se moglo ustvrditi i za prisilu kao drugi element značajan za koncept transfera. Ipak, ti uvidi ne umanjuju eksplanacijsku važnost studija transfera. Dapače, time se njihova primjenjivost potencijalno može proširiti i na analize promjena kao $i$ na analize stabilnosti javnih politika, i to u različitim arenama. Čini se da su recentnija promišljanja i terminološka inoviranja novih oblika transfera (poput kočenja ili nepotpunog transfera) na tragu takvog obuhvatnijeg poimanja studija transfera.

Dakle, eksplanacija promjene javnih politika treba biti integrativna, usustavljujući odnose između eksternih i internih dinamika. Tako 'zašto' promjene javne politike može biti izvanjski uvjetovano, iako zadnja riječ pripada unutarnjim karakteristikama i razvojima (Capano, 2013: 454).

Iz svega dosad navedenog očito je kako su unutar studija transfera kao temeljni kauzalni mehanizmi (a koji se ipak najčešće definiraju kao motori ili generatori promjene - ne stabilnosti) prepoznati učenje i prisila. No svojim fokusom na proces stvaranja javnih politika i na djelovanje različitih aktera studije transfera odbacuju “"nomotehničku' predodžbu kauzalnosti” (Capano, 2009: 17) te tragaju za kauzalnim kombinacijama koje objašnjavaju kako dolazi do promjene. Stone će ustvrditi kako je transfer politika specifičan tip promjene javnih politika koji nastaje kao posljedica učenja o javnim politikama, a ukoliko se nailazi na prepreke prilikom diferencijacije dobrovoljnog i prisilnog transfera, tomu ne treba pristupiti kao "analitičkom problemu, već radije kao analitičkom tragu" (Grin i Loeber, 2007: 204). To se čini i primjerenim odgovorom na ranije iznesene kritike: ako se analiza transfera javnih politika ne može razlikovati od normalnih procesa stvaranja javnih politika, tada je to (važan) analitički trag o naravi tih normalnih procesa.

... čini se da su koncepti učenja o javnim politikama / transfera javnih politika dosegli punoljetnost. Prvo, uključena je i potanko objašnjena uloga nevladinih aktera (...). Drugo, (...) pozornost je usmjerena na (...) ulogu različitih tipova aktera (...). Treće, (...) elaborirana je interakcija između strukture i djelovanja. Uzeti zajedno, ti elementi nude dobru osnovu za potpuno razvijenu teoriju promjene javnih politika putem transfera javnih politika između različitih domena - što je od očite važnosti u transnacionalnom svijetu (ibid.: 205, naglasak Grin i Loeber).

Unatoč tom dosezanju punoljetnosti koje proklamiraju John Grin i Anne Loeber, čini se smislenim rad završiti i nagovještajima mogućih budućih smjerova razvoja studija transfera javnih politika. Pritom ćemo se voditi razmatranjima ključnih autora studija Dolowitza, Marsha i Evansa. Unatoč raznovrsnom i ponekad neočekivanom razvoju tog istraživačkog pristupa, navedeni autori detektiraju i manjkavosti koje bi trebale poslužiti kao impetus daljnjeg razvitka. Primjerice, Evans predlaže 65 hipoteza kao vodilje za buduća istraživanja transfera razvrsta- 
nih u cjeline koje prepoznaje kao ključne za objašnjenja promjena javnih politika: globalna, internacionalna i transnacionalna objašnjenja; objašnjenja fokusirana na države te objašnjenja fokusirana na organizacije (Evans, 2017a). Općenito se sugestije navedenih autora mogu sažeti sljedećim naznakama: transfer kao nezavisna varijabla, motivacije aktera za transfer javnih politika, transfer i novi oblici javnog upravljanja, transfer i stvaranje javnih politika utemeljeno na dokazima, transfer i uspjeh javnih politika, transfer javnih politika iz vlastite prošlosti te višesmjerni transfer javnih politika (Dolowitz, 2017; Dolowitz i Marsh, 2012; Evans, 2017b; 2018; Marsh i Evans, 2012b).

Prvo, dosadašnja istraživanja prvenstveno su se fokusirala na transfer javnih politika kao nezavisnu varijablu nastanka ili razvoja različitih posebnih javnih politika poput socijalne, kaznene, obrazovne i sl. Treba uložiti veći napor u istraživanje kako, zašto i pod kojim uvjetima dolazi do različitih oblika transfera javnih politika - odnosno transfer tretirati kao zavisnu varijablu u istraživačkom dizajnu. Drugo, nedovoljno dosadašnjih istraživanja posvećeno je motivaciji aktera za iniciranje i/ili sudjelovanje $u$ transferu javnih politika. Pritom bi se trebala posvetiti posebna pažnja pitanjima suprotstavljanja transferu - koje su strategije (diskurzivne ili realne) kojima se služe oponenti. Općenito gledano, diskurzivno uokvirivanje odnosno simbolička upotreba transfera (tzv. političke igre aktera transfera) posebno je zanimljivo područje koje dosad nije bilo značajnije analizirano. Uzevši u obzir učestalost korištenja međunarodnih obveza kao legitimacijskog diskursa, dodatna istraživanja o strategijama diskurzivnog uokvirivanja i diskurzivnih borbi mogu oplemeniti važnim uvidima (Dolowitz, 2017; Dolowitz i Marsh, 2012; Marsh i Evans, 2012b).

Treće, dosadašnja istraživanja ukazala su na kompatibilnost određenih oblika transfera s tipovima javnog upravljanja (hijerarhijski, tržišni, mrežni). Čini se posebno produktivnim produbiti te uvide i povezati ih sa širom literaturom o javnom upravljanju. Četvrto, dobrovoljni transfer javnih politika čini se iznimno sukladan sve većoj literaturi o stvaranju javnih politika utemeljenoj na dokazima te se međusobno nadopunjavanje te literature čini poželjnim. Peto, dosad se nedovoljno analitičke pažnje posvetilo uspjehu transferiranih javnih politika. No kako bi se taj aspekt istraživanja mogao unaprijediti, nužno je unutar studija transfera ponuditi i zaokruženu konceptualizaciju uspješnih javnih politika. Šesto, dosadašnja istraživanja primarno su se bavila prostornom dimenzijom transfera. Bilo bi zanimljivo analitički fokus usmjeriti $\mathrm{k}$ transferu javnih politika unutar istog političkog djelokruga - k vremenskoj dimenziji transfera. Odnosno postaviti pitanja o tome zašto i kako se uspješna javnopolitička rješenja iz prošlosti zaboravljaju i zamjenjuju suboptimalnim novim rješenjima. I konačno, više pozornosti treba posvetiti višesmjernom i višerazinskom aspektu transfera. Može se pretpostaviti barem pet razi- 
na (transnacionalna, internacionalna, nacionalna, regionalna i lokalna) na kojima se odvija transfer - što pak čini minimalno 25 dihotomnih scenarija odnosno puteva transfera koji zaslužuju dublju analizu (Evans, 2017b: 27). Nije izgledno da će se, u vremenu globalne agore (Stone, 2008), broj tih odnosa vrijednih analitičke pažnje smanjiti (Dolowitz, 2017; Dolowitz i Marsh, 2012; Evans, 2017a; 2018; Marsh i Evans, 2012b).

\section{Zaključak}

Kao što je prikazano u ovome radu, studije transfera distinktivne su u odnosu na studije konvergencije i difuzije. Odlikuje ih procesni analitički fokus, usmjerenost na razumijevanje djelovanja aktera, kvalitativna metodologija te korištenje malih uzoraka. U ovome radu zastupa se mišljenje kako su studije transfera javnih politika izvrstan heuristički alat jer omogućuju multidimenzionalno istraživanje procesa stvaranja javnih politika. Izučavati se mogu - pojedinačno ili skupno - uzrok transfera, sadržaj transfera i uspjeh transfera. Simplistički rečeno, studije transfera omogućuju da se specificiraju tvrdnje kako je neka javna politika nastala zbog izvanjskih utjecaja te da se elaborira: je li ona nastala zbog pritisaka ili dobrovoljnim učenjem iz iskustva drugih; nadalje jesu li tuđa javnopolitička rješenja kopirana ili se njima inspiriralo; i konačno, je li preuzeto rješenje, zbog konteksta koji nadilazi podsustav javnih politika, uspješno ili potpuno promašeno?

Osim toga, smatra se kako studije transfera imaju veći potencijal za praćenje razvoja javnih politika od točke $\mathrm{A}$ do točke $\mathrm{B}$ odnosno dijakroničnu analizu. Time se u analizu uključuje i istraživanje raznovrsnih motivacija i strategija aktera. Ono što studije transfera javnih politika čini posebno aktualnim i svrsishodnim jest što razmatraju utjecaje poput globalizacije tržišta, razvoja tehnologija te transnacionalnih i internacionalnih institucija i organizacija - a koji su svi u dijalektičkom odnosu u ovome sve kompleksnijem procesu stvaranja javnih politika. Ne možemo se ne složiti s Evansom koji analizu transfera javnih politika smatra:

vrijednim poljem istraživanja unutar kojeg je moguće integriranje zajedničkih istraživačkih interesa znanstvenika nacionalne, komparativne i međunarodne politike - pod uvjetom da pruža lupu za promatranje promjenjive prirode nacionalne države i uloge državnih aktera i institucija u promicanju novih oblika složene globalizacije (Evans, 2017a: 211-212).

Istraživački fokus koji navedeni autor koristi u svojoj posljednjoj knjizi može poslužiti kao dobar putokaz utoliko što se analiziraju transferi javnih politika između nacionalnih država u različitim stupnjevima razvoja: između razvijenih država, od razvijenih prema državama u razvoju, između država u razvoju kao i od država u razvoju prema razvijenim državama (Evans, 2017b). Ipak, ne bismo se trebali za- 
ustaviti na etatističkim komparacijama. Kao što je u ovom tekstu prikazano, potencijal primjene studija transfera transcendira granice nacionalnog procesa stvaranja javnih politika. Studije transfera javnih politika možda nisu fino kalibrirana velika teorija, ali njihovom aplikacijom odgovara se na nužnost istraživanja kompleksne međuovisnosti današnjeg svijeta.

\section{LITERATURA}

Bennett, Colin J. 1991. What is Policy Convergence and What Causes It? British Journal of Political Science, (21), 2: 215-233.

Benson, David i Jordan, Andrew. 2011. What Have We Learned from Policy Transfer Research? Dolowitz and Marsh Revisited. Political Studies Review, (9), 3: 366-378.

Benson, David i Jordan, Andrew. 2012. Policy Transfer Research: Still Evolving, Not Yet Through? Political Studies Review, (10), 3: 333-338.

Börzel, Tanja A. 1998. Organizing Babylon - On the Different Conceptions of Policy Networks. Public Administration, (76), 2: 253-273.

Bulmer, Simon i dr. 2007. Policy Transfer in European Union Governance. Regulating the Utilities. Routledge. New York i London.

Capano, Giliberto. 2009. Understanding policy change as an epistemological and theoretical problem. Journal of Comparative Policy Analysis, (11), 1: 7-31.

Capano, Giliberto. 2013. Policy dynamics and change. The never-ending puzzle, u: Araral, E. i dr. (ur.): Routledge Handbook of Public Policy. Routledge. Abingdon: 451461.

Cairney, Paul. 2012. Understanding Public Policy: Theories and Issues. Basingstoke: Palgrave Macmillan.

Dolowitz, David P. 2009. Learning by observing: surveying the international arena. Policy \& Politics, (37), 3: 317-334.

Dolowitz, David P. 2017. Transfer and Learning: One Coin Two Elements. Novos Estudos, 107: 35-56.

Dolowitz, David P. i Marsh, David. 1996. Who learns what from whom: A review of the policy transfer literature. Political Studies, (44), 2: 343-357.

Dolowitz, David P. i Marsh, David. 2000. Learning from Abroad: The Role of Policy Transfer in Contemporary Policy-Making. Governance: An International Journal of Policy and Administration, (13), 1: 5-24.

Dolowitz, David P. i Marsh, David. 2012. The Future of Policy Transfer Research. Political Studies Review, (10), 3: 339-345.

Dussauge-Laguna, Mauricio I. 2012. On The Past and Future of Policy Transfer Research: Benson and Jordan Revisited. Political Studies Review, (10) 3: 313-324. 
Evans, Mark. 2009a. New directions in the study of policy transfer. Policy Studies, (30), 3: $237-241$.

Evans, Mark. 2009b. Policy transfer in critical perspective. Policy Studies, (30), 3: 243268.

Evans, Mark. 2017a. In conclusion - policy transfer in global perspective, u: Evans, M. (ur.): Policy Transfer in Global Perspective. Taylor \& Francis. Abingdon i New York: 211-226.

Evans, Mark. 2017b. Understanding policy transfer, u: Evans, M. (ur.): Policy Transfer in Global Perspective. Taylor \& Francis. Abingdon i New York: 10-42.

Evans, Mark. 2018. International Policy Transfer: Between Global and Sovereign and Between Global and Local, u: Stone, D. i Molone, K. (ur.): Handbook on Global Public Policy and Transnational Administration. Oxford University Press. Oxford: u tisku.

Evans, Mark i Davies, Jonathan. 1999. Understanding policy transfer: A multi-level, multi-disciplinary perspective. Public Administration, (77), 2: 361-385.

Fink-Hafner, Danica. 2011. The Political Instrumentalisation of Policy Analysis. Politička misao, (48), 5: 25-39.

Grdešić, Ivan. 1995. Političko odlučivanje. Alinea. Zagreb.

Grin, John i Loeber, Anne. 2007. Theories of Policy Learning: Agency, Structure, and Change, u: Fischer, F. i dr. (ur.): Handbook of Public Policy Analysis. Theory, Politics, and Methods. CRC Press. Boca Raton: 201-219.

Hague, Rod i dr. 2001. Komparativna vladavina i politika. Fakultet političkih znanosti. Zagreb.

Hill, Michael. 2010. Proces stvaranja javnih politika. Fakultet političkih znanosti. Zagreb.

Holzinger, Katharina i Knill, Christoph. 2005. Causes and conditions of cross-national policy convergence. Journal of European Public Policy, (12), 5: 775-796.

Hooghe, Liesbet i Marks, Gary. 2003. Unraveling the Central State, but How? Types of Multi-Level Governance. American Political Science Review, (97), 2: 233-243.

Howlett, Michael i Cashore, Benjamin. 2009. The dependent variable problem in the study of policy change: Understanding policy change as a methodological problem. Journal of Comparative Policy Analysis, (11), 1: 33-46.

Howlett, Michael i Ramesh, M. 1995. Studying Public Policy: Policy Cycles and Policy Subsystems. Oxford University Press. Toronto.

Hrcak.srce.hr. 2017. Hrčak. Portal znanstvenih časopisa Republike Hrvatske. https://hrcak.srce.hr/. Pristupljeno 16. kolovoza 2017.

Hupe, Peter L. i Hill Michael J. 2006. The Three Action Levels of Governance: Re-framing the Policy Process Beyond the Stages Model, u: Peters, G. B. i Pierre, J. (ur.): Handbook of Public Policy. Sage. Thousand Oaks: 13-30. 
James, Oliver i Lodge, Martin. 2003. The Limitations of 'Policy Transfer' and 'Lesson Drawing' for Public Policy Research. Political Studies Review, (1), 2: 179-193.

Jordan, Andrew. 2005. Policy convergence: a passing fad or a new integrating focus in European Union studies? Journal of European Public Policy, (12), 5: 944-953.

Keck, Margaret E. i Sikkink, Kathryn. 1999. Transnational Advocacy Networks in International and Regional Politics. International Social Science Journal, (51), 159: 89-101.

Keohane, Robert O. i Nye, Joseph S. Jr. 2000. Globalization: What's New? What's Not? (And so What?). Foreign policy, 118: 104-119.

Knill, Christoph. 2005. Introduction: Cross-national policy convergence: concepts, approaches and explanatory factors. Journal of European Public Policy, (12), 5: 764-774.

Kustec Lipicer, Simona. 2007. Tipologiziranje policy igrača u Europskoj Uniji: dileme i perspektive. Politička misao, (43), 4: 25-46.

Lajh, Damjan. 2007. Zajednička kohezijska politika i višerazinsko odlučivanje u Europskoj Uniji. Politička misao, (43), 4: 3-24.

Landman, Todd. 2008. Teme i metode komparativne politike. Fakultet političkih znanosti. Zagreb.

Marsh, David i Evans, Mark. 2012a. Policy Transfer: Coming of Age and Learning from the Experience. Policy Studies, (33), 6: 477-481.

Marsh, David i Evans, Mark. 2012b. Policy Transfer: Into the Future, Learning from the Past. Policy Studies, (33), 6: 587-591.

Marsh, David i Sharman, Jason C. 2009. Policy diffusion and policy transfer. Policy Studies, (30), 3: 269-288.

Marsh, David i Stoker, Gerry. 2005. Teorije i metode političke znanosti. Fakultet političkih znanosti. Zagreb.

Massey, Andrew. 2009. Policy Mimesis in the Context of Global Governance. Policy Studies, (30), 3: 383-395.

Mataković, Hrvoje. 2011. Transfer javnih politika u politici financiranja političkih stranaka; usporedba Njemačke, Nizozemske i Hrvatske. Anali Hrvatskog politološkog društva, (8), 1: 203-229.

McCann, Eugene i Ward, Kevin. 2012. Policy Assemblages, Mobilities and Mutations: Toward a Multidisciplinary Conversation. Political Studies Review, (10), 3: 325-332.

Mossberger, Karen. 2008. Policy Diffusion, u: Berman, E. M. i Rabin, J. (ur.): Encyclopedia of Public Administration and Public Policy. Taylor \& Francis. New York i London: 1482-1486.

Newmark, Adam J. 2002. An Integrated Approach to Policy Transfer and Diffusion. Review of Policy Research, (19), 2: 151-178. 
Petak, Zdravko. 2007. Javne politike: razvoj discipline u Hrvatskoj i svijetu, u: Kasapović, M. (ur.): Izlazak iz množine? Stanje hrvatske političke znanosti. Fakultet političkih znanosti. Zagreb: 187-217.

Petak, Zdravko. 2014. Javno upravljanje, u: Petek, A. i Petković, K. (ur.): Pojmovnik javnih politika. Političke analize. Zagreb: 96-97.

Petek, Ana. 2014a. Promjena javnih politika, u: Petek, A. i Petković, K. (ur.): Pojmovnik javnih politika. Političke analize. Zagreb: 137-138.

Petek, Ana. 2014b. Transfer javnih politika, u: Petek, A. i Petković, K. (ur.): Pojmovnik javnih politika. Političke analize. Zagreb: 164-165.

Petek, Ana i Petković, Krešimir (ur.). 2014. Pojmovnik javnih politika. Političke analize. Zagreb.

Petković, Krešimir. 2017. Transfer kaznene politike: slučaj Engleske i Walesa. Zbornik Pravnog fakulteta Sveučilišta u Rijeci, (38), 2: 745-777.

Radaelli, Claudio M. 2000. Policy Transfer in the European Union: Institutional Isomorphism as a Source of Legitimacy. Governance: An International Journal of Policy and Administration, (13), 1: 25-43.

Real-Dato, José. 2009. Mechanisms of policy change: a proposal for a synthetic explanatory framework. Journal of Comparative Policy Analysis, (11), 1: 117-143.

Rose, Richard. 1993. Lesson-Drawing in Public Policy: A Guide to Learning across Time and Space. Chatham House Publishers. Chatham.

Sabatier, Paul A. 1998. The Advocacy Coalition Framework: Revisions and Relevance for Europe. Journal of European Public Policy, (5), 1: 98-130.

Stachowiak, Sarah. 2013. Pathways for change: 6 theories about how policy change happens. Organizational Research Services, http://orsimpact.com/wp-content/ uploads/2013/08/pathways_for_change_6_theories_about_how_policy_change happens.pdf, posjećeno 28. srpnja 2015.

Stone, Diane. 2001. Learning Lessons, Policy Transfer and the International Diffusion of Policy Ideas. Working Paper 69. Centre for the Study of Globalisation and Regionalisation. University of Warwick. Coventry.

Stone, Diane. 2004. Transfer Agents and Global Networks in the 'transnationalization' of Policy. Journal of European Public Policy, (11), 3: 545-566.

Stone, Diane. 2008. Global Public Policy, Transnational Policy Communities, and Their Networks. Policy Studies Journal, (36), 1: 19-38.

True, Jacqui. 2015. Osvještavanje globalnih javnih politika rodom, u: Šinko, M. (ur.): Žene i politika: feministička politička znanost. Centar za ženske studije i Fakultet političkih znanosti. Zagreb: 447-479.

Žiljak, Tihomir. 2006. Europski konvergencijski procesi i zamke nepripremljenih transfera obrazovnih politika. Političko obrazovanje, (2), 3-4: 96-115. 


\title{
Marjeta Šinko
}

\section{CONTEMPORARY PUBLIC POLICY PROCESSES: HOW TO RESEARCH POLICY TRANSFER?}

\begin{abstract}
Summary
From the second half of the twentieth century policy scholars are increasingly devoting their attention to the transference of policy from one political jurisdiction to another. Concepts such as policy diffusion, convergence and transfer are being used to elucidate the modern-day policy process. Policy transfer, the youngest of these approaches, has been gaining momentum from the second half of the nineties and has grown into a respectable, widely cited and used research frame. This article is a historical account of policy transfer research. In addition to examining the evolution of similar approaches (diffusion, convergence, and transfer), the original systematization and demarcation of different studies is offered. The paper concludes with the insight that policy transfer studies are distinctive in relation to convergence and diffusion studies. They are characterized by an analytical focus on processes, on understanding of policy actors' actions, on qualitative methodology, and using small samples. The paper concludes that policy transfer studies are an excellent heuristic tool because they enable a multidimensional research of the policy process.
\end{abstract}

Keywords: Public Policies, Transfer, Diffusion, Convergence, Policy Change

Dr. sc. Marjeta Šinko je poslijedoktorandica na Fakultetu političkih znanosti Sveučilišta u Zagrebu.

Kontakt: Marjeta Šinko, Fakultet političkih znanosti, Sveučilište u Zagrebu, Lepušićeva 6, 10000 Zagreb. E-mail: marjeta.sinko@fpzg.hr 